\title{
PENERAPAN MODEL PEMBELAJARAN AKTIF-KOOPERATIF TIPE LSA TERHADAP PENINGKATAN HASIL BELAJAR SISWA SMA PADA SUBKONSEP SISTEM IMUN MANUSIA
}

\author{
Reni Ernawati, S.Pd ${ }^{1}$, Dr. Uus Toharudin, M.Pd ${ }^{2}$ \\ Drs. Yusuf Ibrahim, M.Pd.,M.P ${ }^{3}$., Ida Yayu Nurul Hizqiyah, S.Pd., M.Si ${ }^{4}$ \\ ${ }^{1}$ Sekolah Pascasarjana UPI \\ ${ }^{2,3,4}$ Pendidikan Biologi FKIP Universitas Pasundan \\ 1reniernawati17@gmail.com \\ 4iynh_biokipas@yahoo.com
}

\begin{abstract}
This study aims to determine high school student learning outcomes by implementing active learning model-type cooperative Listen-Say-Arrange (LSA) on subconcepts human immune system. The method used in this study is a QuasiExperimental research design Static group pretest-posttest design, through procurement control class. The population of this research is a class XI IPA at SMAN 10 Bandung, with a sample of two classes, namely class XI IPA 1 (as the control group) and XI IPA 2 (as a class experiment). The research instrument used is an objective test that measures cognitive domain in the form of multiple choice of 20 items given through pretest and posttest. Based on the analysis of research data, obtained by the average value $(x)$ pretest control class that uses conventional learning models (lectures) at 52.62 and the average value $(x)$ posttest at 68.91. While in the classroom experimentation that use active learning model-type cooperative LSA, obtained average value $(x)$ pretest at 56.58 and the average value $(x)$ posttest at 77.58. Having in mind the results of pretest and posttest each class then performed $t$-test, then the results obtained $t$-test value of pretest and posttest control class with thitung (4.85)> t0,01 (66) (2.66) were significantly different, as well as the t-test results and the value pretest posttest experimental class thitung (8.54)> t0,01 (72) (2.65) which means significantly different as well. Testing continued with the calculation of the N-Gain, which gained control class $\mathrm{N}$-Gain of 0.34 and obtain experimental class $\mathrm{N}$-gain of 0.48 . Criteria value $\mathrm{N}$-Gain in control class and experimental class are equally included in the medium category. From these results it can be concluded that the application of active learning model-type cooperative subconcepts LSA on the human immune system can improve student learning outcomes.
\end{abstract}

Keywords: active learning model-type cooperative LSA, learning outcomes, the human immune system 


\section{Didaktik : J urnal Pendidikan Guru Sekolah Dasar, ISSN : 2477-5673 \\ Sekolah Tinggi Keguruan dan IImu Pendidikan Subang Volume II Nomor 1, Desember 2016}

\section{ABSTRAK}

Penelitian ini bertujuan untuk mengetahui hasil belajar siswa SMA dengan menerapkan model pembelajaran aktif-kooperatif tipe Listen-Say-Arrange (LSA) pada subkonsep sistem imun manusia. Metode yang digunakan dalam penelitian ini adalah Quasi-Experimental dengan desain penelitian Static Group PretestPosttest Design, melalui pengadaan kelas kontrol. Populasi dari penelitian ini adalah kelas XI IPA SMA Negeri 10 Bandung, dengan sampel sebanyak 2 kelas, yaitu kelas XI IPA 1 (sebagai kelas kontrol) dan XI IPA 2 (sebagai kelas eksperimen). Instrumen penelitian yang digunakan adalah tes objektif yang mengukur ranah kognitif dalam bentuk pilihan ganda sebanyak 20 butir soal yang diberikan melalui pretest dan posttest. Berdasarkan analisis data hasil penelitian, diperoleh nilai rata-rata $(\bar{x})$ pretest kelas kontrol yang menggunakan model pembelajaran konvensional (ceramah) sebesar 52,62 dan nilai rata-rata $(\bar{x})$ posttest sebesar 68,91. Sedangkan pada kelas eskperimen yang menggunakan model pembelajaran aktif-kooperatif tipe $L S A$, diperoleh nilai rata-rata $(\bar{x})$ pretest sebesar 56,58 dan nilai rata-rata $(\bar{x})$ posttest sebesar 77,58. Setelah diketahui hasil pretest dan posttest tiap kelas maka dilakukan uji-t, kemudian diperoleh hasil uji-t nilai pretest dan posttest kelas kontrol dengan $t_{\text {hitung }}(4,85)>t_{0,01}(66)(2,66)$ yang berbeda secara signifikan, serta pada hasil uji-t nilai pretest dan posttest kelas eksperimen dengan $t_{\text {hitung }}(8,54)>t_{0,01}(72)(2,65)$ yang berarti berbeda secara signifikan pula. Pengujian dilanjutkan dengan perhitungan N-Gain, dimana kelas kontrol memperoleh N-Gain sebesar 0,34 dan kelas eksperimen memperoleh $\mathrm{N}$ gain sebesar 0,48. Kriteria nilai N-Gain pada kelas kontrol dan kelas eksperimen sama-sama termasuk dalam kategori sedang. Dari hasil penelitian ini dapat disimpulkan bahwa penerapan model pembelajaran aktif-kooperatif tipe LSA pada subkonsep sistem imun manusia dapat meningkatkan hasil belajar siswa.

Kata kunci: Model pembelajaran aktif-kooperatif tipe LSA, hasil belajar, sistem imun manusia

\section{A. PENDAHULUAN}

\section{Latar Belakang Masalah}

Mengajar bukan semata

persoalan menceritakan dan belajar bukan merupakan konsekuensi otomatis dari penuangan informasi ke dalam benak siswa. Belajar memerlukan keterlibatan mental dan kerja siswa sendiri. Penjelasan dan pemeragaan semata tidak akan membuahkan hasil belajar yang optimal (Silberman, 2012: 9).

Ketika peserta didik pasif atau hanya menerima pelajaran dari guru, ada kecenderungan untuk cepat melupakan pelajaran yang telah diberikan. Menurut Samadhi (2008: 46), siswa belajar hanya $10 \%$ dari apa 


\section{Didaktik : J urnal Pendidikan Guru Sekolah Dasar, ISSN : 2477-5673 \\ Sekolah Tinggi Keguruan dan Ilmu Pendidikan Subang Volume II Nomor 1, Desember 2016}

yang dibaca, $20 \%$ dari apa yang didengar, 30\% dari apa yang dilihat, $50 \%$ dari apa yang dilihat dan didengar, $70 \%$ dari apa yang dikatakan, dan 90\% dari apa yang dikatakan dan dilakukan. Hal ini menunjukkan bahwa jika mengajar dengan banyak ceramah, maka tingkat pemahaman siswa hanya $20 \%$.

Tetapi sebaliknya, jika siswa diminta untuk belajar secara aktif, tingkat pemahaman siswa dapat mencapai sekitar $90 \%$.

Kegiatan Belajar Mengajar (KBM) merupakan kegiatan siswa dalam membangun makna atau pemahaman. Tanggung jawab belajar berada pada diri siswa, dan guru bertanggung jawab untuk menciptakan situasi yang mendorong prakarsa, potensi, motivasi, tanggung jawab dan kerja sama siswa dalam belajar (Astari, 2010: 1).

Namun pada kenyataannya masih banyak guru yang cenderung memegang paradigma lamanya, dengan menganggap otak seorang anak ibarat botol kosong yang siap diisi dengan segala ilmu pengetahuan dan kebijaksanaan dari sang maha guru (Lie, 2008: 2).

Tentu saja hal tersebut berdampak menjadi masalah dalam proses pembelajaran, yakni didapati para siswa yang kurang mampu memahami materi yang disampaikan oleh gurunya. Maka dari itu, dalam pelaksanaannya guru diharapkan dapat memilih dan merancang model pembelajaran yang tepat agar tercipta suatu kondisi belajar yang kondusif yang memungkinkan semua siswa merasa termotivasi, senang dan tertantang untuk melakukan kegiatan belajar sehingga dapat meningkatkan prestasi hasil belajarnya.

Purwati (2010: 67) telah melakukan penelitian terhadap siswa yang pembelajarannya menggunakan model pembelajaran aktif pada mata pelajaran biologi (materi pencemaran). Hasilnya, siswa yang menggunakan model pembelajaran aktif memperoleh peningkatan hasil belajar dibandingkan dengan siswa yang memperoleh pembelajaran biasa (ceramah saja).

Subratha (2007: 145) pun menjelaskan mengenai penerapan model pembelajaran kooperatif yang dapat meningkatkan capaian kompetensi dasar siswa (aspek kognitif) pada mata pelajaran fisika dari siklus-1 sampai dengan siklus-3 pada penelitiannya. 


\section{Didaktik : J urnal Pendidikan Guru Sekolah Dasar, ISSN : 2477-5673 \\ Sekolah Tinggi Keguruan dan IImu Pendidikan Subang Volume II Nomor 1, Desember 2016}

Dari kedua penelitian tersebut dapat disimpulkan bahwa model pembelajaran aktif dan model pembelajaran kooperatif dapat meningkatkan hasil belajar siswa. Oleh karena itu, bermula dari rasa keingintahuan dan ketertarikannya, penulis bermaksud untuk melakukan penelitian dengan menggabungkan penerapan model pembelajaran aktif dan model pembelajaran kooperatif terhadap peningkatan hasil belajar siswa dalam pembelajaran biologi.

Model pembelajaran yang digunakan dalam penelitian ini adalah model pembelajaran aktif-kooperatif tipe Listen-Say-Arrange (LSA). Model ini dipilih dengan alasan karena belum pernah ada penelitian sebelumnya yang menggunakan model pembelajaran aktif-kooperatif tipe LSA. Model pembelajaran aktifkooperatif tipe $L S A$ adalah model pembelajaran yang menuntun siswa untuk berperan aktif dalam kegiatan pembelajaran, dimana akan terdapat komunikasi dan partisipasi positif antarsiswa dalam kelompoknya. Model pembelajaran ini melibatkan tiga tahap dasar, yaitu listen (mendengarkan), say (mengatakan) dan arrange (menyusun) (Hizqiyah, 2011; Ratmiwati, 2012).
Adapun materi yang diambil penulis dalam penelitian ini adalah subkonsep sistem imun manusia. Meskipun sistem imun ini sering dianggap tidak terlalu penting dalam hal pengajarannya dan terkadang diabaikan, namun sebenarnya sangat berhubungan sekali dengan kehidupan sehari-hari siswa. Sistem imun ini merupakan perlindungan dan pertahanan utama bagi tubuh manusia.

\section{Rumusan Masalah}

Berdasarkan latar belakang masalah yang telah diuraikan, maka dapat dirumuskan permasalahan yang akan diungkap dalam penelitian ini yaitu: "Apakah dengan menerapkan model pembelajaran aktif-kooperatif tipe $L S A$ dapat meningkatkan hasil belajar siswa SMA pada subkonsep sistem imun manusia?"

\section{Batasan Masalah}

Mengingat keterbatasan dalam berbagai hal dan untuk menghindari meluasnya masalah, maka penulis membatasi permasalahannya sebagai berikut:

a. Subjek Penelitian

Subjek pada penelitian ini adalah siswa kelas XI IPA SMA Negeri 10 


\section{Didaktik : J urnal Pendidikan Guru Sekolah Dasar, ISSN : 2477-5673 \\ Sekolah Tinggi Keguruan dan IImu Pendidikan Subang Volume II Nomor 1, Desember 2016}

Bandung semester 2 tahun ajaran 2011/2012, dengan kelas yang dipilih ialah sebanyak dua kelas berdasarkan nilai rata-rata hasil belajar siswa yang sedang, yakni kelas XI IPA 1 sebanyak 34 orang sebagai kelas kontrol dan XI IPA 2 sebanyak 37 orang sebagai kelas eksperimen.

b. Objek Penelitian

Objek pada penelitian ini adalah model pembelajaran aktif-kooperatif tipe $L S A$.

c. Materi Penelitian

Materi yang digunakan dalam penelitian ini adalah mengenai subkonsep sistem imun manusia yang mencakup pengertian dan fungsi sistem imun, mekanisme pertahanan tubuh alami, mekanisme pertahanan tubuh buatan, respon imun nonspesifik serta respon imun spesifik.

c. Parameter Penelitian

Parameter yang diukur dalam penelitian ini adalah hasil belajar siswa yang ditunjukkan pada aspek kognitif berbentuk tes secara tertulis (pretest dan posttest), dengan membandingkan kelas kontrol dan kelas eksperimen.

\section{Tujuan Penelitian}

Tujuan umum penelitian ini yaitu untuk mengetahui hasil belajar siswa SMA dengan menerapkan model pembelajaran aktif-kooperatif tipe $L S A$ pada subkonsep sistem imun manusia. Adapun tujuan khusus penelitian ini, diantaranya untuk:

1. Mengetahui kemampuan penguasaan siswa pada subkonsep sistem imun manusia sebelum dan setelah diterapkan model pembelajaran aktif-kooperatif tipe LSA.

2. Mengetahui peningkatan hasil belajar siswa pada subkonsep sistem imun manusia setelah penerapan model pembelajaran aktif-kooperatif tipe $L S A$.

\section{B. LANDASAN TEORI}

Model pembelajaran aktifkooperatif adalah model pembelajaran yang dapat digunakan untuk meningkatkan aktivitas siswa dan mampu menumbuhkan kemampuan bekerja sama, menjadikan siswa belajar aktif, kreatif, serta berpikir kritis, karena siswa dalam kelompoknya dituntun untuk terlibat langsung dalam proses pembelajaran, sehingga pembelajaran yang bermakna mampu dirasakan oleh siswa, dan hasil yang diinginkan dapat tercapai.

Pada awalnya, model pembelajaran aktif-kooperatif tipe 


\section{Didaktik : J urnal Pendidikan Guru Sekolah Dasar, ISSN : 2477-5673 \\ Sekolah Tinggi Keguruan dan Ilmu Pendidikan Subang Volume II Nomor 1, Desember 2016}

Listen-Say-Arrange (LSA) ini bernama

"I Can Share with You, You Can

Share with Me", dengan cakupan dua tahap dasar (Listen yang berarti mendengar dan Say yang berarti mengatakan) (Hizqiyah, 2011). Namun dengan seiring waktu dan perkembangan pola pemikiran, model ini berganti nama menjadi "LSA" dengan cakupan yang bertambah pula menjadi tiga tahap dasar, yakni Listen yang berarti mendengar, Say yang berarti mengatakan dan Arrange yang berarti menyusun (Ratmiwati, 2012). Hizqiyah (2011); Ratmiwati (2012) menyatakan bahwa model pembelajaran aktif-kooperatif tipe $L S A$ menuntun siswa untuk berperan aktif dalam kegiatan pembelajaran (tidak hanya menghafal dari materi yang diberikan oleh guru), dimana akan terdapat partisipasi positif antarsiswa dalam kelompoknya. Model pembelajaran ini melibatkan tiga tahap dasar, yaitu: (1) Listen (mendengarkan beberapa kata kunci dari konsep tertentu); (2) Say (mengatakan informasi mengenai kata-kata kunci yang telah didengarnya); dan (3) Arrange (menyusun semua kata kunci yang ada menjadi sebuah bahasan konsep yang utuh serta menyeluruh).
Model pembelajaran aktifkooperatif tipe $L S A$ dalam kegiatan pembelajarannya menyajikan peserta didik belajar secara efektif untuk berproses meningkatkan kemampuan dalam memahami materi kompetensi dengan menikmati proses pembelajaran dan menumbuhkan motivasi belajar sehingga membuat pembelajaran terasa lebih dalam serta hasil kegiatan belajar yang berjalan optimal (Nugroho, 2010: 119; Hizqiyah, 2011; Ratmiwati, 2012).

Menurut Hizqiyah (2011); Ratmiwati (2012), terdapat beberapa hal yang perlu diperhatikan dalam menerapkan model pembelajaran aktif-kooperatif tipe $L S A$, antara lain:

a. Harus sesuai dengan kondisi dimana tempat siswa itu berada dan materi apa yang akan dipelajari.

b. Tidak efektif dilaksanakan pada kelas dengan jumlah siswa yang terlalu besar karena bimbingan guru tidak akan dapat berjalan maksimal.

\section{Subkonsep Sistem Imun Manusia}

Sistem imun adalah sistem pertahanan tubuh terhadap serangan "benda asing" (antigen) dan patogen (mikroorganisme penyebab penyakit) 


\section{Didaktik : J urnal Pendidikan Guru Sekolah Dasar, ISSN : 2477-5673 \\ Sekolah Tinggi Keguruan dan IImu Pendidikan Subang Volume II Nomor 1, Desember 2016}

yang masuk ke dalam tubuh (Aryulina, et al., 2007: 333).

Aryulina, et al. (2007: 321) mengemukakan bahwa sistem imun memiliki beberapa fungsi bagi tubuh, yaitu sebagai: (a) penangkal "benda asing" yang masuk ke dalam tubuh; (b) untuk keseimbangan fungsi tubuh terutama menjaga keseimbangan komponen tubuh yang telah tua; dan (c) pendeteksi adanya sel-sel abnormal, termutasi atau ganas, serta menghancurkannya.

Kebanyakan patogen yang ada di sekitar kita sulit masuk ke dalam tubuh akibat adanya mekanisme pertahanan tubuh secara alami. Terdapat empat jenis mekanisme pertahanan tubuh alami terhadap patogen yang akan masuk ke dalam tubuh, yaitu pertahanan fisik melalui kulit dan air mata, pertahanan mekanik dengan adanya rambut hidung, pertahanan kimia dengan enzim lisozim dan $\mathrm{HCl}$, pertahanan biologis seperti flora alami/bakteri tidak berbahaya (Aryulina, et al., 2007: 322).

Selain itu pula, ada yang dinamakan dengan mekanisme pertahanan tubuh buatan terhadap patogen yang akan masuk ke dalam tubuh, salah satunya yaitu melalui vaksinasi. Vaksinasi merupakan pemberian vaksin ke dalam tubuh seseorang untuk memberikan kekebalan terhadap penyakit tersebut. Vaksin adalah bibit penyakit yang telah dilemahkan (zat cair yang mengandung patogen yang telah lemah atau mati) dan berperan sebagai antigen yang akan memacu tubuh membentuk antibodi guna melawan patogen. Vaksin diperoleh dari sumber-sumber berikut, yakni: mikroorganisme mematikan yang dimatikan, strain hidup yang tidak mematikan, toksin yang dimodifikasi, antigen hasil isolasi dan antigen hasil rekayasa genetika (Aryulina, et al., 2007: 328-330).

Setiap saat tubuh kita menghadapi radiasi, zat-zat asing, mikroorganisme dan sebagainya yang disebut dengan bibit penyakit. Tubuh kita memiliki kemampuan untuk melawan bibit penyakit, yang disebut dengan daya tahan tubuh (respon tubuh). Daya tahan tubuh (respon imun) dibedakan menjadi dua, yaitu respon imun non-spesifik dan respon imun spesifik (Kurnadi, 2002: 146).

Respon imun non-spesifik yaitu respon imun yang efektif terhadap semua mikroorganisme atau berbagai bibit penyakit yang selektif, artinya 


\section{Didaktik : J urnal Pendidikan Guru Sekolah Dasar, ISSN : 2477-5673 \\ Sekolah Tinggi Keguruan dan IImu Pendidikan Subang Volume II Nomor 1, Desember 2016}

tubuh tidak harus mengenal dahulu jenis bibit penyakitnya serta tidak harus memilih hanya satu bibit penyakit tertentu saja untuk dihancurkannya. Respon imun nonspesifik berupa inflamasi (peradangan) dan fagositosis (Kurnadi, 2002: 146).

Respon imun spesifik yaitu respon imun yang khusus (spesifik) untuk jenis bibit penyakit tertentu saja. $\mathrm{Hal}$ ini mencakup pengenalan dahulu terhadap bibit penyakit, kemudian memproduksi antibodi khusus yang hanya akan bereaksi terhadap bibit penyakit tersebut (Kurnadi, 2002: 147).

Respon imun spesifik timbul dari dua sistem berbeda yang saling bekerja sama, yaitu imunitas humoral dan imunitas selular (Aryulina, et al., 2007: 325).

\section{METODOLOGI PENELITIAN}

Metode yang digunakan pada penelitian ini adalah QuasiExperimental (eksperimen semu) dengan tujuan untuk memperoleh informasi yang merupakan perkiraan bagi informasi yang dapat diperoleh dengan eksperimen yang sebenarnya dalam keadaan yang tidak memungkinkan untuk mengontrol semua variabel yang relevan (Purwati, 2010: 43).

Dalam penelitian ini terdapat kelas eksperimen dan kelas kontrol. Kelas eksperimen diberi perlakuan dengan Proses Belajar Mengajar (PBM) yang menggunakan model pembelajaran aktif-kooperatif tipe $L S A$ dan kelas kontrol diberi perlakuan dengan PBM yang menggunakan model pembelajaran konvensional (ceramah).

Desain yang digunakan dalam penelitian ini adalah Static Group Pretest-Posttest Design (Sugiyono, 2008: 112 dalam Tresnawati, et al., 2011: 192).

Adapun rancangan desain penelitian dapat dilihat pada Tabel 6.1

Tabel 6.1. Desain Penelitian

\begin{tabular}{|c|c|r|r|}
\hline $\begin{array}{c}\text { Kelo } \\
\text { mpok }\end{array}$ & $\begin{array}{c}\text { rete } \\
\text { st }\end{array}$ & $\begin{array}{r}\mathbf{P} \\
\text { erlaku } \\
\text { an }\end{array}$ & $\begin{array}{r}\mathbf{P} \\
\text { osttes } \\
\mathbf{t}\end{array}$ \\
\hline $\begin{array}{c}\text { Eksperime } \\
\mathrm{n}\end{array}$ & 1 & $\mathrm{X}$ & $\mathrm{O}$ \\
\hline Kontrol & & $\mathrm{Y}$ & $\mathrm{O}$ \\
\hline
\end{tabular}

(Sumber: Sugiyono, 2008: 112 dalam Tresnawati, et al., 2011: 192)

Keterangan:

$\mathrm{O}_{1}=$ Pretest dan $\mathrm{O}_{2}=$ Posttest 
$\mathrm{X}=$ PBM dengan menggunakan model pembelajaran aktif-kooperatif tipe $L S A$

$\mathrm{Y}=\mathrm{PBM}$ dengan menggunakan model pembelajaran konvensional (ceramah)

\section{HASIL PENELITIAN}

Data hasil penelitian ini didapatkan melalui kegiatan pretest (tes awal) dan posttest (tes akhir). Data tersebut diambil pada subkonsep sistem imun manusia, dari kelas yang mendapat pembelajaran dengan menggunakan model pembelajaran aktif-kooperatif tipe LSA (kelas eksperimen) dan kelas yang hanya mendapat pembelajaran dengan perlakuan kontrol menggunakan model pembelajaran konvensional atau ceramah (kelas kontrol).

Data pretest dan posttest diperoleh dari 20 butir soal tes objektif berbentuk pilihan ganda dengan lima pilihan jawaban, yang mana sebelumnya telah diuji terlebih dahulu dengan uji validitas, reliabilitas, daya pembeda dan tingkat kesukaran soalnya.

Data-data hasil pretest dan posttest akan dianalisis dengan uji normalitas menggunakan Chi-Kuadrat $\left(\mathrm{X}^{2}\right)$, uji homogenitas menggunakan uji Bartlett, pengujian hipotesis menggunakan uji-t dan perhitungan tingkat keefektifan pembelajaran dengan menggunakan Normalized Gain (N-Gain). Berikut ini akan disajikan satu persatu mengenai datadata tersebut.

Perbandingan hasil belajar siswa dengan menggunakan model pembelajaran konvensional (ceramah) pada kelas kontrol dan model pembelajaran aktif-kooperatif tipe $L S A$ pada kelas eksperimen dapat dilihat pada Gambar 7.1.

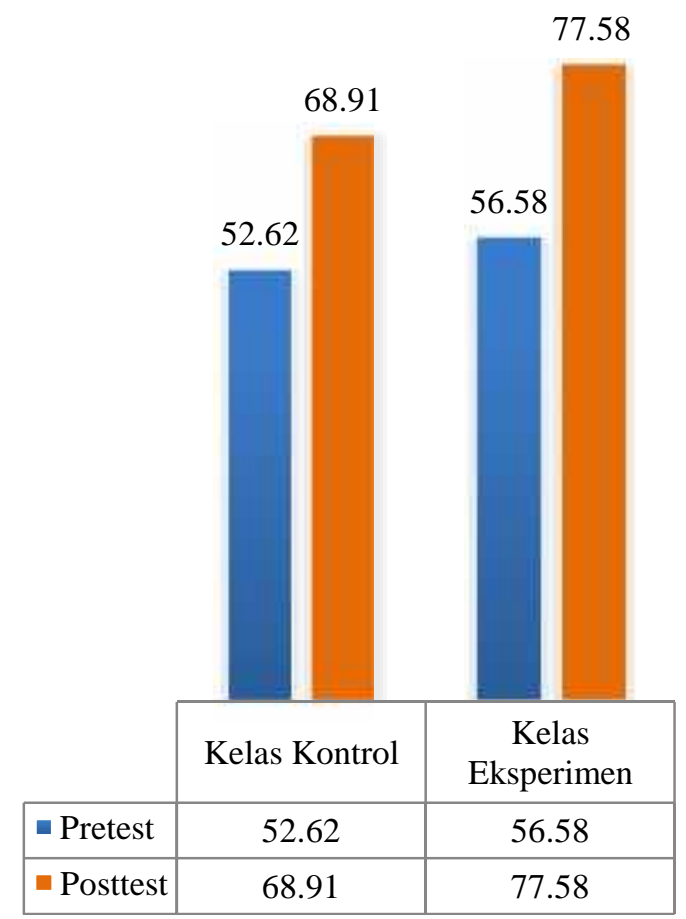

Gambar 7.1. Grafik Perbandingan Antara Nilai Rata-rata Pretest dan Posttest pada Kelas Kontrol dan Kelas Eksperimen 
1. Data Hasil Pretest dan Posttest

Adapun rincian data hasil tes yang diperoleh dari nilai pretest dan posttest, tercantum pada Tabel 7.1.

Tabel 7.1. Data Hasil Pretest dan Posttest

\begin{tabular}{|c|c|c|c|c|}
\hline \multirow{2}{*}{ Nilai } & \multicolumn{3}{|c|}{ Data Hasil Penelitian } \\
\cline { 2 - 5 } & \multicolumn{2}{|c|}{$\begin{array}{c}\text { Kelas } \\
\text { Kontrol }\end{array}$} & \multicolumn{2}{c|}{$\begin{array}{c}\text { Kelas } \\
\text { Eksperime } \\
\text { n }\end{array}$} \\
\cline { 2 - 5 } & Pretest & Posttest & $\begin{array}{c}\text { Pret } \\
\text { est }\end{array}$ & $\begin{array}{c}\text { Post } \\
\text { test }\end{array}$ \\
\hline$\overline{\mathbf{x}}$ & 52,62 & 68,91 & $\begin{array}{c}56,5 \\
8\end{array}$ & $\begin{array}{c}77,5 \\
8\end{array}$ \\
\hline $\mathbf{S}$ & 14,59 & 13,43 & $\begin{array}{c}11,0 \\
2\end{array}$ & 9,45 \\
\hline $\mathbf{N}$ & 34 & 34 & 37 & 37 \\
\hline $\begin{array}{c}\text { Nilai } \\
\text { Min }\end{array}$ & 15 & 40 & 30 & 55 \\
\hline $\begin{array}{c}\text { Nilai } \\
\text { Max }\end{array}$ & 80 & 85 & 80 & 95 \\
\hline N-Gain & \multicolumn{2}{|c|}{0,34} & & \multicolumn{3}{|c|}{0,48} \\
\hline
\end{tabular}

Berdasarkan Tabel 7.1., dapat diketahui bahwa nilai rata-rata hasil belajar siswa yang menggunakan model pembelajaran aktif-kooperatif tipe LSA lebih besar dibandingkan dengan nilai rata-rata hasil belajar siswa yang menggunakan model pembelajaran konvensional (ceramah). Pada kelas kontrol, nilai rata-rata pretest siswa adalah 52,62 dan nilai rata-rata posttest adalah 68,91 dengan selisih sebesar 16,29. Pada kelas eksperimen, nilai rata-rata pretest siswa adalah 56,58 dan nilai rata-rata posttest adalah 77,58 dengan selisih sebesar 21. Jika dilihat kepada nilai $N$-Gain masing-masing kelas yaitu kelas kontrol dan kelas eksperimen, terdapat perbedaan selisih angka sebesar 0,14, dimana tingkat keefektifan pembelajaran kelas kontrol dengan menggunakan model pembelajaran konvensional (ceramah) lebih rendah dibandingkan dengan kelas eksperimen yang menggunakan model pembelajaran aktif-kooperatif tipe $L S A$, yakni dapat dilihat perbandingannya 0,34 (untuk kelas kontrol) < 0,48 (untuk kelas eksperimen).

\section{Analisis Data Hasil Pretest dan Posttest}

Penganalisisan data hasil pretest dilakukan untuk memperoleh informasi dan mengetahui seberapa jauh kemampuan pemahaman awal siswa sebelum proses pembelajaran berlangsung. Sedangkan penganalisisan data hasil posttest dilakukan untuk memperoleh informasi dan mengetahui seberapa besar hasil belajar siswa setelah proses pembelajaran berlangsung, yakni penerapan model pembelajaran konvensional (ceramah) pada kelas kontrol serta penerapan model pembelajaran aktif-kooperatif tipe $L S A$ pada kelas eksperimen.

Adapun tahapan dalam penganalisisan data hasil pretest dan 
posttest tersebut adalah sebagai berikut:

\section{a. Uji Normalitas}

Uji normalitas pada penelitian ini dengan menggunakan Chi-Kuadrat $\left(\mathrm{X}^{2}\right)$ karena jumlah data lebih dari 30. Adapun hasil uji normalitas dapat dilihat pada Tabel 7.2.

Tabel 7.2. Hasil Uji Normalitas

$$
\text { Pretest }
$$

\section{dan Posttest pada Kelas Kontrol dan Kelas Eksperimen}

\begin{tabular}{|c|c|c|c|c|c|}
\hline \multirow{2}{*}{$\begin{array}{l}\text { Jenis } \\
\text { Tes }\end{array}$} & \multicolumn{2}{|c|}{$\begin{array}{c}\text { Kelas } \\
\text { Kontrol }\end{array}$} & \multicolumn{2}{|c|}{\begin{tabular}{|c|} 
Kelas \\
Eksperimen
\end{tabular}} & \multirow{2}{*}{$\begin{array}{r}\text { Kesim- } \\
\text { pulan }\end{array}$} \\
\hline & $\begin{array}{l}X^{2} \\
\text { hit }\end{array}$ & $\begin{array}{c}X^{2} \\
0,01\end{array}$ & $\begin{array}{l}\mathbf{X}^{2} \\
\text { hit }\end{array}$ & $\begin{array}{l}X^{2} \\
0,01\end{array}$ & \\
\hline Pre-test & 1,89 & 13,3 & 5,97 & 13,3 & $\begin{array}{c}\text { Data } \\
\text { berdis- } \\
\text { tribusi } \\
\text { normal }\end{array}$ \\
\hline Post-test & 11,23 & 11,3 & 3,33 & 13,3 & $\begin{array}{c}\text { Data } \\
\text { berdis- } \\
\text { tribusi } \\
\text { normal }\end{array}$ \\
\hline
\end{tabular}

Berdasarkan Tabel 7.2., dapat dilihat bahwa pada kelas kontrol dan kelas eksperimen baik pada data hasil pretest maupun posttest berdistribusi normal, karena $X^{2}$ hitung lebih rendah daripada $X^{2}$ tabel pada taraf signifikan $\alpha$ $=0,01$ atau $X^{2}$ hitung $<X^{2}{ }_{0,01}$. Data hasil pretest kelas kontrol dan kelas eksperimen memiliki nilai $X^{2}$ hitung $=$ 1,89 dan 5,97 yang lebih kecil daripada $X^{2}{ }_{0,01}(4)=13,3$. Begitu juga dengan data hasil posttest kelas kontrol memiliki nilai $X^{2}{ }_{\text {hitung }}=11,23$ yang lebih kecil daripada $X_{0,01}^{2}$ (3) $=$ 11,3 dan kelas eksperimen memiliki nilai $X^{2}$ hitung $=3,33$ yang lebih kecil daripada $X_{0,01(4)}^{2}=13,3$.

\section{b. Uji Homogenitas}

Setelah diketahui bahwa data hasil pretest dan posttest berdistribusi normal, maka selanjutnya dilakukan uji homogenitas. Uji homogenitas ini dengan menggunakan uji Bartlett. Berdasarkan uji Bartlett, varians dari nilai pretest dan posttest dikatakan homogen jika $X^{2}{ }_{\text {hitung }}<\mathrm{X}^{2}$ tabel.

Berikut ini adalah Tabel 7.3. yang menunjukkan hasil uji homogenitas:

Tabel 7.3. Hasil Uji Homogenitas Pretest

dan Posttest pada Kelas Kontrol dan Kelas Eksperimen

\begin{tabular}{|c|c|c|c|}
\hline Kelas & $\mathbf{X}_{\text {hitung }}$ & $\mathbf{X}_{0,01}^{2}$ & $\begin{array}{c}\text { Kesimp } \\
\text { ulan }\end{array}$ \\
\hline Kontrol & 0,25 & 6,63 & $\begin{array}{c}\text { Varians } \\
\text { Homoge } \\
n\end{array}$ \\
\hline Eksperimen & 0,86 & 6,63 & $\begin{array}{c}\text { Varians } \\
\text { Homoge } \\
n\end{array}$ \\
\hline
\end{tabular}

Berdasarkan Tabel 7.3., hasil uji homogenitas pada kelas kontrol dan kelas eksperimen yakni nilai pretest dan posttest menunjukkan bahwa $\mathrm{X}^{2}$ hitung lebih rendah daripada $\mathrm{X}^{2}$ tabel 


\section{Didaktik : J urnal Pendidikan Guru Sekolah Dasar, ISSN : 2477-5673 \\ Sekolah Tinggi Keguruan dan IImu Pendidikan Subang Volume II Nomor 1, Desember 2016}

pada taraf signifikan $\alpha=0,01$ atau $\mathrm{X}^{2}{ }_{\text {hitung }}<\mathrm{X}^{2}{ }_{0,01}$. Maka data pretest dan posttest pada masing-masing kelas mempunyai varians yang homogen. Data hasil pretest dan posttest kelas kontrol memiliki nilai $X^{2}$ hitung $=0,25$ yang lebih kecil daripada $X^{2}{ }_{0,01(1)}=$ 6,63. Begitu juga dengan data hasil pretest dan posttest kelas eksperimen memiliki nilai $X^{2}$ hitung $=0,86$ yang lebih kecil daripada $\quad X_{0,01(1)}^{2}=6,63$.

\section{c. Uji Hipotesis}

Pengujian hipotesis pada kelas kontrol dan kelas eksperimen mencakup data hasil pretest dan posttest dengan menggunakan uji-t, karena kedua data tersebut berdistribusi normal, mempunyai varians yang homogen dan jumlah data lebih dari 30. Uji hipotesis ini dilakukan dengan tujuan untuk mencari apakah terdapat perbedaan yang signifikan antara nilai siswa sebelum belajar (pretest) dan setelah belajar (posttest) dengan membandingkan nilainya pada kelas kontrol dan kelas eksperimen. Melalui penerapan model pembelajaran konvensional (ceramah) pada kelas kontrol dan penerapan model pembelajaran aktif-kooperatif tipe $L S A$ pada kelas eksperimen dengan masing-masing bahasan yang sama yaitu pada subkonsep sistem imun manusia.

Adapun hasil uji hipotesis (uji-t) dapat dilihat pada Tabel 7.4.

Tabel 7.4. Hasil Uji Hipotesis (Uji-t) Pretest dan Posttest pada Kelas

Kontrol dan Kelas Eksperimen

\begin{tabular}{|c|c|c|c|}
\hline Kelas & $\mathbf{t}_{\text {hitung }}$ & $\mathbf{t}_{\mathbf{0 , 0 1}}$ & Keterangan \\
\hline Kontrol & 4,85 & 2,66 & $\mathrm{H}_{\circ}$ ditolak \\
\hline Eksperimen & 8,54 & 2,65 & $\mathrm{H}_{\mathrm{o}}$ ditolak \\
\hline \multicolumn{2}{|c|}{ Kesimpulan: } & terdapat
\end{tabular}
perbedaan yang signifikan atau berbeda nyata antara nilai rata-rata pretest serta posttest pada kelas kontrol dan kelas eksperimen.

Pada Tabel 7.4. menunjukkan bahwa terdapat perbedaan yang signifikan antara nilai rata-rata pretest serta posttest pada kelas kontrol dan kelas eksperimen, bahwa $t_{\text {hitung }}$ lebih tinggi daripada $t_{\text {tabel }}$ pada taraf signifikan $\alpha=0,01$ atau $t_{\text {hitung }}>t_{0,01}$. Dimana kelas kontrol menunjukkan nilai $t_{\text {hitung }}=4,85$ yang lebih besar daripada $t_{0,01}(66)=2,66$. Begitu juga dengan kelas eksperimen menunjukkan nilai $t_{\text {hitung }}=8,54$ yang lebih besar daripada $t_{0,01}(72)=2,65$. Hal ini mengartikan bahwa terdapat perbedaan yang cukup jelas dimana kelas eksperimen menunjukkan angka yang lebih tinggi dibandingkan dengan kelas kontrol. 
Didaktik : J urnal Pendidikan Guru Sekolah Dasar, ISSN : 2477-5673

Sekolah Tinggi Keguruan dan IImu Pendidikan Subang

Volume II Nomor 1, Desember 2016

Berdasarkan hasil penganalisisan tersebut, telah dapat diketahui bahwa nilai hasil belajar siswa antara kelas yang menggunakan model pembelajaran konvensional (ceramah) dengan kelas yang menggunakan model pembelajaran aktif-kooperatif tipe $L S A$ terdapat perbedaan yang nyata/signifikan, serta dapat diketahui bahwa penerapan model pembelajaran aktif-kooperatif tipe $L S A$ lebih baik dibandingkan dengan model pembelajaran

konvensional (ceramah).

3. Analisis Perhitungan Nilai NGain

Nilai $N$-Gain dapat menunjukkan tingkat keefektifan (efektivitas) peningkatan suatu pembelajaran yang diterapkan, dalam hal ini yaitu penerapan model pembelajaran konvensional (ceramah) pada kelas kontrol dan penerapan model pembelajaran aktif-kooperatif tipe $L S A$ pada kelas eksperimen. Dalam perhitungan nilai $\mathrm{N}$-Gain ini, dilakukan perbandingan nilai rata-rata hasil pretest dan nilai rata-rata hasil posttest.

Deskripsi data nilai $N$-Gain (gain yang dinormalisasi) dapat dilihat pada Tabel 7.5.
Tabel 7.5. Hasil Perhitungan Nilai N-

Gain (g) Rata-rata Pretest dan

Posttest

pada Kelas Kontrol dan Kelas

Eksperimen

\begin{tabular}{|c|r|c|c|c|c|}
\hline \multirow{2}{*}{ Kelas } & \multicolumn{2}{|c|}{$\begin{array}{c}\text { Nilai Rata- } \\
\text { rata }\end{array}$} & G ain & N- \\
\cline { 2 - 5 } & $\begin{array}{r}\text { Pre-- } \\
\text { test }\end{array}$ & $\begin{array}{c}\text { Post } \\
\text { test }\end{array}$ & $\begin{array}{c}\text { Kri- } \\
\text { teria }\end{array}$ \\
\hline Kontrol & 52,62 & 68,91 & 16,29 &, 34 & $\begin{array}{c}\text { Se- } \\
\text { dang }\end{array}$ \\
\hline Ekspe-rimen & 56,58 & 77,58 & 21 &, 48 & $\begin{array}{c}\text { Se- } \\
\text { dang }\end{array}$ \\
\hline \multicolumn{2}{|r|}{ Berdasarkan Tabel 7.5., terdapat } \\
\hline
\end{tabular}

perbedaan selisih angka sebesar 0,14 antara nilai $N$-Gain (g) pada kelas kontrol dan nilai $N$-Gain (g) pada kelas eksperimen, dimana tingkat keefektifan pembelajaran kelas kontrol dengan menggunakan pembelajaran konvensional (ceramah) lebih rendah dibandingkan dengan kelas eksperimen yang menggunakan model pembelajaran aktif-kooperatif tipe $L S A$, yakni dapat dilihat perbandingannya 0,34 (untuk kelas kontrol) < 0,48 (untuk kelas eksperimen). Namun mengenai kriteria nilai $N$-Gain untuk masingmasing kelas (kelas kontrol dan kelas eksperimen) tersebut sama-sama termasuk dalam kategori sedang.

\section{E. PEMBAHASAN}

Penguasaan konsep awal siswa dilihat dari nilai pretest. Nilai rata-rata pretest siswa pada kelas kontrol 
adalah 52,62, sedangkan pada kelas eksperimen adalah 56,58. Dalam pretest, nilai minimum yang ditemukan pada kelas kontrol yaitu 15, sedangkan pada kelas eksperimen yaitu 30. Kemudian nilai maksimum pretest yang diperoleh pada kelas kontrol dan kelas eksperimen yaitu 80 . Pada nilai minimum pretest, terdapat rentang yang tidak terlalu jauh hanya dengan selisih 15, serta nilai maksimum pretest pada dua kelas sama yakni 80. Adapun Kriteria Ketuntatasan Minimal (KKM) yang harus dicapai dalam mata pelajaran Biologi di kelas XI IPA SMA Negeri 10 Bandung yaitu 73 , oleh sebab itu masih cukup banyak siswa yang belum mencapai KKM tersebut. Pada pretest di kelas kontrol, siswa yang mendapatkan nilai di atas KKM yaitu hanya dua orang (sekitar 5,88\%) dan yang mendapatkan nilai di bawah KKM yaitu 32 orang (sekitar 94,12\%). Pada pretest di kelas eksperimen pun tidak berbeda jauh, dengan siswa yang nilainya berada di atas KKM yaitu hanya dua orang (sekitar 5,41\%) dan yang nilainya berada di bawah KKM yaitu 35 orang (sekitar 94,60\%).

Banyaknya nilai siswa yang belum mampu mencapai KKM tersebut merupakan indikasi atau wujud dari pemilihan dan penerapan model pembelajaran yang kurang tepat selama PBM berlangsung.

Penguasaan konsep siswa setelah diberikannya pembelajaran berupa materi sistem imun manusia pada kedua kelas mengalami perbedaan yang cukup jauh. Pengujian setelah diberikan materi tersebut berupa posttest. Pada kelas kontrol dengan menggunakan model pembelajaran konvensional (ceramah) yakni diperoleh nilai rata-rata sebesar 68,91 dan pada kelas eksperimen dengan menggunakan model pembelajaran aktif-kooperatif tipe $L S A$ diperoleh nilai rata-rata sebesar 77,58. Pada kelas kontrol, nilai minimum yang dicapai pada posttest adalah 40 dan nilai maksimumnya adalah 85 . Kelas eksperimen menunjukkan nilai minimum pada angka 55 dan nilai maksimum pada angka 95.

Berdasarkan

perhitungan distribusi nilai siswa pada posttest ini menunjukkan cukup banyak siswa yang mendapatkan nilai di atas KKM. Pada kelas kontrol, jumlah siswa yang nilainya berada di atas KKM yaitu 16 orang (sekitar 47,06\%) dan yang nilainya berada di bawah KKM yaitu 18 orang (sekitar 52,94\%). Sedangkan pada kelas eksperimen, jumlah siswa 


\section{Didaktik : J urnal Pendidikan Guru Sekolah Dasar, ISSN : 2477-5673 Sekolah Tinggi Keguruan dan IImu Pendidikan Subang Volume II Nomor 1, Desember 2016}

yang mendapatkan nilai di atas KKM yaitu 28 orang (sekitar 75,68\%) dan yang mendapatkan nilai di bawah KKM yaitu hanya sembilan orang (sekitar 24,32\%). Hal ini memberikan gambaran yang sangat jelas bahwa adanya peningkatan nilai siswa yang berbeda pada kelas kontrol dan kelas eksperimen, yang dipengaruhi oleh penerapan model pembelajaran yang tepat untuk memperkuat pemahaman siswa dalam menguasai bahan ajar sebagai capaian pembelajarannya di sekolah.

Berdasarkan perhitungan gain, pada kelas kontrol sebelum siswa melaksanakan kegiatan belajar dengan model pembelajaran konvensional (ceramah), nilai rata-rata pretest sebesar 52,62, sedangkan pada hasil belajar siswa setelah melaksanakan kegiatan belajar didapat nilai rata-rata posttest sebesar 68,91. Selisih nilai rata-rata (gain) yang diperoleh yaitu 16,29. Pada kelas kontrol ini menunjukkan siswa yang mengalami peningkatan hasil belajar sejumlah 26 orang, sisanya ada dua orang siswa yang mengalami penurunan hasil belajar dan enam orang siswa yang tidak mengalami peningkatan maupun penurunan hasil belajar (statis). Hasil uji hipotesis dengan menggunakan uji-t menunjukkan nilai $t_{\text {hitung }}$ sebesar 4,85 dan $t_{\text {tabel }}(0,01)(66)$ sebesar 2,66 . Oleh karena itu, nilai $t_{\text {hitung }}$ berada di luar daerah penerimaan $\mathrm{H}_{0}$, maka dapat disimpulkan bahwa $\mathrm{H}_{\mathrm{o}}$ ditolak, artinya pada penerapan model pembelajaran konvensional (ceramah) terhadap kelas kontrol mengalami peningkatan hasil belajar siswa pada subkonsep sistem imun manusia secara signifikan atau berbeda nyata.

Pada kelas eksperimen, sebelum siswa melaksanakan kegiatan belajar dengan model pembelajaran aktifkooperatif tipe $L S A$, nilai rata-rata pretest sebesar 56,58, sedangkan pada hasil belajar siswa setelah melaksanakan kegiatan belajar didapat nilai rata-rata posttest sebesar 77,58. Selisih nilai rata-rata (gain) yang diperoleh yaitu 21. Pada kelas eksperimen ini menunjukkan seluruh siswa sejumlah 37 orang mengalami peningkatan hasil belajar. Hasil uji hipotesis dengan menggunakan uji-t menunjukkan nilai $t_{\text {hitung }}$ sebesar 8,54 dan $t_{\text {tabel }}(0,01)$ (72) sebesar 2,65. Oleh karena itu, nilai $t_{\text {hitung }}$ berada di luar daerah penerimaan $\mathrm{H}_{0}$, maka dapat disimpulkan bahwa $\mathrm{H}_{\mathrm{o}}$ ditolak, artinya penerapan model pembelajaran aktifkooperatif tipe LSA terhadap kelas 


\section{Didaktik : J urnal Pendidikan Guru Sekolah Dasar, ISSN : 2477-5673 \\ Sekolah Tinggi Keguruan dan IImu Pendidikan Subang Volume II Nomor 1, Desember 2016}

eksperimen dapat meningkatkan hasil belajar siswa pada subkonsep sistem imun manusia secara signifikan atau berbeda nyata.

Berdasarkan hasil analisis data pada uji hipotesis dengan menggunakan uji-t menunjukkan bahwa terdapat perbedaan yang signifikan antara nilai rata-rata pretest serta posttest pada kelas kontrol dan kelas eksperimen, bahwa $t_{\text {hitung }}$ lebih tinggi daripada $t_{\text {tabel }}$ pada taraf signifikan $\alpha=0,01$ atau $t_{\text {hitung }}>t_{0,01}$. Dimana kelas kontrol menunjukkan nilai $t_{\text {hitung }}=4,85$ yang lebih besar daripada $t_{0,01}(66)=2,66$. Begitu juga dengan kelas eksperimen menunjukkan nilai $t_{\text {hitung }}=8,54$ yang lebih besar daripada $t_{0,01}(72)=2,65$. Hal ini mengartikan bahwa terdapat perbedaan yang cukup jelas dimana kelas eksperimen menunjukkan angka yang lebih tinggi dibandingkan dengan kelas kontrol.

Pada analisis data tahap terakhir dengan membandingkan nilai N-Gain, terdapat perbedaan selisih angka sebesar 0,14 antara nilai $N$-Gain (g) pada kelas kontrol dan nilai $N$-Gain (g) pada kelas eksperimen, dimana tingkat keefektifan pembelajaran kelas kontrol dengan menggunakan pembelajaran konvensional (ceramah) lebih rendah dibandingkan dengan kelas eksperimen yang menggunakan model pembelajaran aktif-kooperatif tipe $L S A$, yakni dapat dilihat perbandingannya 0,34 (untuk kelas kontrol) $<0,48$ (untuk kelas eksperimen). Namun mengenai kriteria nilai $N$-Gain untuk masingmasing kelas (kelas kontrol dan kelas eksperimen) tersebut sama-sama termasuk dalam kategori sedang. Hal ini menandakan besarnya angka efektivitas dari suatu model pembelajaran dapat membuktikan bahwa model pembelajaran tersebut (model pembelajaran aktif-kooperatif tipe $L S A$ ) dapat meningkatkan hasil belajar siswa.

Dengan demikian, penelitian yang peneliti lakukan di SMA Negeri 10 Bandung melalui penerapan model pembelajaran aktif-kooperatif tipe $L S A$ pada subkonsep sistem imun manusia, menegaskan bahwa pembelajaran dengan menggunakan model pembelajaran aktif-kooperatif tipe $L S A$ dapat meningkatkan hasil belajar siswa. Adanya perbedaan pencapaian hasil belajar pada kelas kontrol dan kelas eksperimen sebagai akibat dari perbedaan bentuk perlakuan yang diterima siswa, dimana siswa yang diberi perlakuan 


\section{Didaktik : J urnal Pendidikan Guru Sekolah Dasar, ISSN : 2477-5673 \\ Sekolah Tinggi Keguruan dan IImu Pendidikan Subang Volume II Nomor 1, Desember 2016}

dengan model pembelajaran aktifkooperatif tipe $L S A$ menjadi lebih baik hasil belajarnya dibandingkan dengan siswa yang diberi perlakuan dengan model pembelajaran konvensional (ceramah).

Dalam model pembelajaran aktifkooperatif tipe LSA tersebut, terdapat proses dimana siswa belajar secara aktif, menyenangkan dan bersemangat, bergerak leluasa dan berpikir keras. Agar tercipta suasana proses pembelajaran yang menyenangkan tersebut, siswa harus mendapatkan rasa aman dengan menjadi bagian dari kelompok (Silberman, 2012: 9 dan 30).

Berbeda halnya dengan model pembelajaran konvensional (ceramah) yang cenderung lebih membosankan, kurang menarik dan lebih menitikberatkan pada keaktifan guru saja (Purwati, 2010: 65-66).

Jadi dengan menerapkan model pembelajaran aktif-kooperatif tipe $L S A$, siswa tidak hanya menghafal dan duduk pasif untuk mendengarkan materi yang diberikan oleh guru, tetapi siswa dapat belajar secara aktif dan bekerja sama dalam teman kelompoknya sehingga dapat terjadi komunikasi berbagai arah baik antara guru dengan siswa ataupun siswa dengan siswa. Adapun dengan adanya peningkatan hasil belajar pada penerapan model pembelajaran aktifkooperatif tipe LSA tersebut menggambarkan bahwa siswa lebih memahami dan menguasai konsep yang dipelajari.

Model pembelajaran aktifkooperatif tipe LSA dapat diterapkan sebagai bentuk model pembelajaran alternatif yang digunakan dalam proses pembelajaran yang berlangsung di kelas. Model pembelajaran ini sangat efektif diterapkan pada materi pembelajaran yang cukup memuat banyak konsep yang perlu dipahami siswa, dengan cara siswa sendiri yang menyusun bahasan konsep dari materi tersebut. Model pembelajaran aktif-kooperatif tipe $L S A$ dapat juga dijadikan sebagai salah satu upaya guru untuk menciptakan proses pembelajaran yang lebih variatif yang akan meningkatkan hasil belajar siswa dengan tidak menjadikan siswa menjadi aktif tanpa pemahaman dan penguasaan konsep, karena pada hakikatnya pemahaman dan penguasaan konsep siswa terhadap pelajaran dengan cara menggalinya sendiri akan lebih kuat mengingatnya dibandingkan hanya dengan diberikan 
Didaktik : J urnal Pendidikan Guru Sekolah Dasar, ISSN : 2477-5673

Sekolah Tinggi Keguruan dan IImu Pendidikan Subang Volume II Nomor 1, Desember 2016 umpan oleh guru berupa
pembelajaran konvensional (ceramah)
yang membuat siswa kurang aktif dan
menjadi pasif dalam mengikuti
pelajaran.

\section{F. KESIMPULAN}

Berdasarkan analisis data hasil penelitian dan pembahasan yang telah diuraikan sebelumnya, maka penulis dapat menarik kesimpulan sebagai berikut:

Terdapat peningkatan hasil belajar siswa pada subkonsep sistem imun manusia setelah diterapkannya model pembelajaran aktif-kooperatif tipe $L S A$. Hal ini dapat dilihat dari perolehan nilai rata-rata siswa yang semakin meningkat pada kelas eksperimen, kriteria nilai $N$-Gain yang termasuk dalam kategori sedang dan bertambahnya jumlah siswa yang telah mencapai KKM. Selain dilihat dari ketiga aspek tersebut, hal ini didukung pula oleh hasil analisis data uji-t yang menyatakan bahwa terdapat perbedaan yang nyata/signifikan, dimana kelas eksperimen menunjukkan angka yang lebih tinggi dibandingkan dengan kelas kontrol, sehingga dapat diketahui bahwa penerapan model pembelajaran aktifkooperatif tipe $L S A$ lebih baik dibandingkan dengan model pembelajaran konvensional (ceramah).

\section{G. SARAN}

Berdasarkan hasil penelitian yang tergambar dari bahasan sebelumnya, terdapat beberapa saran yang menyangkut penelitian yang telah penulis lakukan, diantaranya:

1. Bagi guru, sekiranya mulai menerapkan model pembelajaran aktif-kooperatif tipe $L S A$ sebagai salah satu alternatif model pembelajaran yang dapat dikembangkan dalam pembelajaran.

2. Bagi siswa, penulis menyarankan hendaklah selalu meningkatkan kreativitas dan aktivitas dalam memanfaatkan kesempatan yang diberikan guru selama pembelajaran.

3. Bagi peneliti berikutnya yang tertarik dengan penelitian ini, penulis menyarankan perlu dilakukan penelitian lebih lanjut untuk menguji sejauh mana efektivitas dari model pembelajaran aktif-kooperatif tipe LSA, diimbangi dengan perencanaan dan persiapan yang lebih matang, seperti dalam menentukan alokasi waktu, 


\section{Didaktik : J urnal Pendidikan Guru Sekolah Dasar, ISSN : 2477-5673 \\ Sekolah Tinggi Keguruan dan Ilmu Pendidikan Subang \\ Volume II Nomor 1, Desember 2016}

menyampaikan langkah-langkah

model pembelajaran aktif-

kooperatif tipe $L S A$, serta

mengatur jumlah kelompok siswa,

yang hendaknya diperhatikan

serta dipertimbangkan dengan

saksama agar penelitian dapat dilakukan sebagaimana mestinya.

4. Bagi sekolah, sebagai bahan masukan untuk perlu memperhatikan sarana dan prasarana yang menunjang pada proses pembelajaran agar dapat meningkatkan prestasi siswa.

\section{DAFTAR PUSTAKA}

Arikunto, S. (2006). Dasar-dasar Evaluasi Pendidikan (Edisi Revisi VI). Jakarta: PT Bumi Aksara.

Arikunto, S. (2010). Prosedur Penelitian Suatu Pendekatan Praktik (Edisi Revisi XIV). Jakarta: PT Rineka Cipta.

Aryulina, D., Muslim, C., Manaf, S., dan Winarni, E.W. (2007). Biologi 2 SMA dan MA untuk Kelas XI. Jakarta: Esis.

Asikin, S.A.M. (2010). Pengaruh Penerapan PQ4R Terhadap Penguasaan Konsep Struktur dan Fungsi Jaringan Tumbuhan pada Siswa SMP. Skripsi Sarjana pada Pendidikan Biologi FPMIPA UPI Bandung: tidak diterbitkan.

Astari, R.W. (2010). Peningkatan Kemampuan Menulis Puisi dengan Model Pembelajaran Mind Mapping pada Siswa Kelas $X$ SMA Negeri 1 Gemolong Tahun Ajaran 2009/2010. [Online]. Tersedia: http://etd.eprints.ums.ac.id/843 5/1/A31006037.pdf. [13 April 2012]

Kurnadi, K.A. (2002). Dasar-dasar Anatomi dan Fisiologi Tubuh Manusia (II). Bandung: Jurusan Pendidikan Biologi FPMIPA Universitas Pendidikan Indonesia.

Lie, A. (2008). Cooperative Learning: Mempraktikkan Cooperative Learning di Ruang-ruang Kelas. Jakarta: PT Grasindo.

Nugroho, D.H. (2010). "Studi Tentang Implementasi Metode

Pembelajaran Aktif Berbasiskan Konstruktivisme untuk Prodi Elektronika-Instrumentasi-

STTN". Makalah pada Seminar Nasional SDM Teknologi Nuklir, tanggal 18 November 2010. Yogyakarta: tidak diterbitkan.

Purwati, R. (2010). Penggunaan Model Active Learning dalam Meningkatkan Penguasaan Konsep Pencemaran pada Siswa Kelas X SMA Negeri 1 Katapang. Skripsi Sarjana pada Pendidikan Biologi FKIP Universitas Pasundan Bandung: tidak diterbitkan.

Samadhi, T.M.A. A. (2008). "Pembelajaran Aktif (Active Learning)". Makalah pada Teaching Improvement Workshop (TIW), Engineering Education Development Project. Jakarta: Depdikbud. 
Silberman, M.L. terjemahan Raisul

Muttaqien. (2012). Active

Learning: 101 Cara Belajar

Siswa Aktif (Edisi Revisi VI).

Bandung: Nuansa.

Subratha, N. (2007). "Pengembangan

Model Pembelajaran Kooperatif

dan Strategi Pemecahan

Masalah untuk Meningkatkan

Hasil Belajar Siswa Kelas VII C

SMP Negeri 1 Sukasada".

Jurnal Penelitian dan

Pengembangan Pendidikan

(JPPP). 1 (2), 135-147.

Sudjana. (2002). Metoda Statistika (Edisi Revisi VI). Bandung: Tarsito.

Suhaerah, L. (2009). Pengantar

Statistika untuk Pendidikan

Biologi. Bandung: Program

Studi Pendidikan Biologi FKIP

Universitas Pasundan

Bandung.

Tresnawati, C., Tapilouw, F.S., dan

Ratnawulan, A. (2011).

"Implementasi Model

Pembelajaran Inkuiri pada

Konsep Sistem Pernapasan

untuk Meningkatkan

Kemampuan Konseptual,

Prosedural dan Sikap IImiah

Siswa". Biosfer: Jurnal IImiah

Pendidikan Biologi dan

Lingkungan Hidup. 3 (2), 189-

202. 